\title{
Closure of meningomyelocele defects using various types of keystone-design perforator island flaps
}

\author{
Nandita Melati Putri, Narottama Tunjung, Patricia Marcellina Sadikin \\ Division of Plastic, Reconstructive, and Aesthetic Surgery, Department of Surgery, Dr. Cipto Mangunkusumo Hospital, Faculty of Medicine \\ Universitas Indonesia, Jakarta, Indonesia
}

\begin{abstract}
Background Various methods have been described to close large meningomyelocele defects, but no technique has been proven superior to others. This study presents cases of meningomyelocele defect closure with a keystone-design perforator island flap.

Methods A retrospective study was performed on 14 patients with meningomyelocele defects closed using various types of keystone flaps.

Results The median age of the patients at surgery was 10.5 days (range, 1-369 days) and the average defect size was $22.5 \mathrm{~cm}^{2}$ (range, 7.1-55.0 $\mathrm{cm}^{2}$ ). The average operative time for defect closure was 89.6 minutes (range, 45-120 minutes). Type IV bilateral keystone flaps were used for four defects, type IV unilateral flaps for six defects, type IIA flaps for two defects, and type III flaps for two defects.

Conclusions All the defects healed completely with no major complications. The keystonedesign perforator island flap is a reliable, easy, and fast technique to close large meningomyelocele defects.
\end{abstract}

Keywords Surgery, plastic / Meningomyelocele / Perforator flaps / Island flaps / Surgical flaps

\author{
Correspondence: \\ Nandita Melati Putri \\ Division of Plastic, Reconstructive, \\ and Aesthetic Surgery, Department of \\ Surgery, Dr. Cipto Mangunkusumo \\ Hospital, Faculty of Medicine \\ Universitas Indonesia, RS Cipto \\ Mangunkusumo, Gedung A Lantai \\ 4, Jalan Diponegoro No. 71, Jakarta \\ Pusat, Jakarta 10430, Indonesia \\ Tel: +62-21-390-5556 \\ Fax: +62-21-314-6938 \\ E-mail: nandita.putri@ui.ac.id
}

\section{INTRODUCTION}

Meningomyelocele is the most common form of neural tube defect, and is caused by a failure of fusion of the vertebral column resulting in cystic herniation of meningeal and spinal cord tissue [1]. The defects mainly occur in the lumbosacral region. Worldwide, the incidence ranges from as low as 0.1 per 1,000 in African children to 12.5 per 1,000 among Celtic children [2]. Its incidence has decreased due to the enforcement of folic acid supplementation, fortification of food, and elective pregnancy termination after early detection of the anomaly. This disease also imposes a high cost of treatment and burden to the family due to the life-long disabilities suffered by affected patients such as paraplegia, incontinence, hydrocephalus, and mental retarda- tion. A mortality rate as high as $35 \%$ has been reported [3]. Early closure of the defects, usually within the first 48-72 hours of life, is recommended to reduce infection-related morbidity and mortality [4]. Soft tissue adjacent to the defect is usually sufficient for primary closure after neural repair [5]. However, coverage of larger defects requires collaboration with plastic surgeons for more complex closure methods [1].

The reconstruction of meningomyelocele defects aims to provide a well-vascularized watertight closure, protect underlying neural tissues, and minimize morbidity $[1,2,6,7]$. Furthermore, the surgery should be quick and easy to perform. The complication rate related to meningomyelocele closures ranges between $0 \%$ and $22.8 \%$, including infection, wound dehiscence, cerebrospinal fluid (CSF) leak, and donor-site morbidity [6-9]. Various 
methods for meningomyelocele defect closure have been described in the literature, including skin grafts, skin flaps with various techniques (Z-plasty, V-Y advancement, rotational, and Limberg), fasciocutaneous flaps with various modifications, and musculocutaneous flaps $[1,2,6,10-12]$. To date, no technique has been proven superior to others.

The keystone-design perforator island flap (KDPIF) was first described by Behan in 1995 [13]. A keystone is defined as an apical, curvilinear stone of Roman arches. A flap that follows this design is used to cover an elliptical defect and optimizes the available tissue surrounding the defect. The flap resembles two or three V-Y island flaps and allows an even distribution of tension along the flap edges after closure [14]. This fasciocutaneous flap has a reliable source of vascularization from the perforator beneath it. This locoregional flap is versatile and can be utilized in various regions of the human body. Our unit has performed KDPIF since 2012 with satisfactory results for soft tissue coverage in the head and neck, scrotum and inguinal area, back, and lower extremities. In this study, we assessed the use of the KDPIF for meningomyelocele defect reconstruction.

\section{METHODS}

\section{Patients}

Fourteen patients with meningomyelocele for whom our plastic surgery division was consulted from August 2013 to November 2020 were enrolled. Ethical approval for this study was obtained from the institutional review board, and the study was performed in accordance with the principles of the Declaration of Helsinki. The patients' guardians provided written informed consent for the publication and the use of their images. The data were collected retrospectively by reviewing patients' medical records. We retrieved the following data: age at surgery, sex, location of the meningomyelocele, size of the defects, type of keystone flap, length of surgery, presence of complications, length of hospital stay (from the day of surgery until discharge from the hospital), and follow-up data. The area of the defect was measured based on the formula described by Musluman et al. [6]. To calculate the area of defects with a circular form, $\pi r^{2}$ was used, while for elliptical defects, $\pi r_{1} r_{2}$ was used ( $r$ is the radius of a circular defect, and $r_{1}$ and $r_{2}$ are the longest and shortest radii of an elliptical defect, respectively).

\section{Surgical technique}

Neural placode dissection and spinal cord and dural reconstruction were performed by the pediatric neurosurgery team. The surgery was then continued by the plastic surgery team. The quality of the adjacent skin and subcutaneous tissue was evalu- ated and non-viable tissue was excised. The size of the defects was measured and the laxity of the surrounding tissue was assessed. The types of keystone flaps used were based on the classification by Behan [13]: type I, the deep fascia is left intact for small defects up to $2 \mathrm{~cm}$; type IIA, the deep fascia along the outer curvilinear line is divided to facilitate tissue mobilization and defect closure; type IIB, the deep fascia is divided and a skin graft is used to cover the secondary defects; type III, two identical opposing flaps are used to create a double keystone flap; and type IV, the flap is rotated and can be raised up to $50 \%$ of the flap subfascially, with a skin graft that can be applied to cover the secondary defects.

Firstly, we identified the location of perforators using a handheld Doppler device. The perforators were marked, and the keystone flap was then drawn with the perforators included in the middle of the flap. The flap was dissected and elevated in the subfascial plane for keystone type II, III, and IV flaps. When we used a unilateral keystone flap, the flap width was drawn at a 1:1 ratio to the defect width. The flap was sutured in various methods to accommodate complete defect closure, including the omega modification of the keystone flap. We recommend placing the final suture lines passing through the midline of the vertebrae to minimize wound breakdown (Fig. 1). When we decided to use a bilateral flap, the total width of both flaps was twice the width of the defect, with each flap width drawn at a 1:1 ratio to the defect width. The axis of the flap could be craniocaudal or laterolateral (Fig. 2). All secondary defects could be closed primarily.

\section{RESULTS}

Fourteen patients with meningomyelocele underwent defect closure with KDPIFs. Nine of the patients were male (64\%).

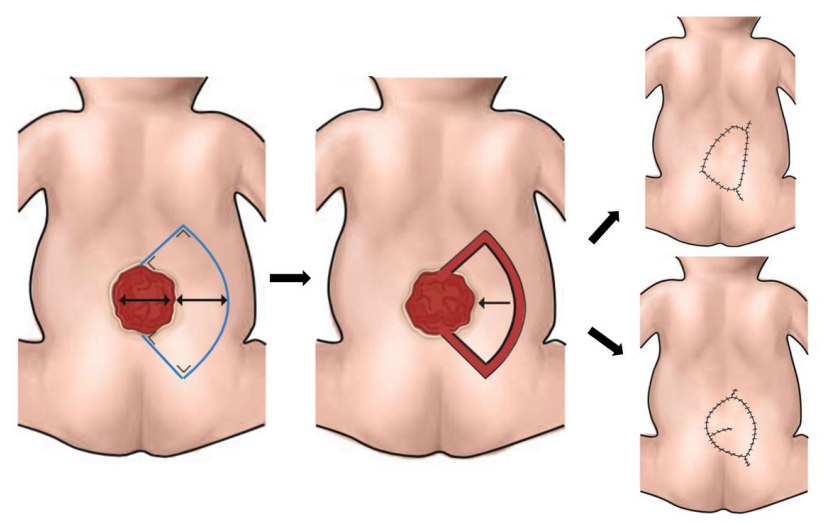

Fig. 1. The unilateral keystone flap design. The flap width is equal to the defect width. The flap can be advanced to the defect using the conventional keystone design or modified using the omega design. The final suture line is placed passing through the midline. 
Seven meningomyelocele defects were located in the thoracolumbar region (50\%), four in the lumbosacral region (29\%), and three in the lumbar region (21\%). The minimum defect size was $3 \times 3 \mathrm{~cm}$ (area, $7.1 \mathrm{~cm}^{2}$ ) and the maximum defect size was $10 \times 7 \mathrm{~cm}$ (area, $55 \mathrm{~cm}^{2}$ ) with an average of $22.5 \mathrm{~cm}^{2}$. The age of the patients at surgery ranged from 1 day to 13 months old. All the defect closures could be accomplished in less than 120 minutes (range, 45-120 minutes), with an average of 89.6 minutes. Bilateral keystone flaps required a longer operative time (average, 115 minutes) than unilateral keystone flaps (average, 70.6 minutes) (Table 1 ).

Two defects were closed with type IIA keystone flaps. Type III
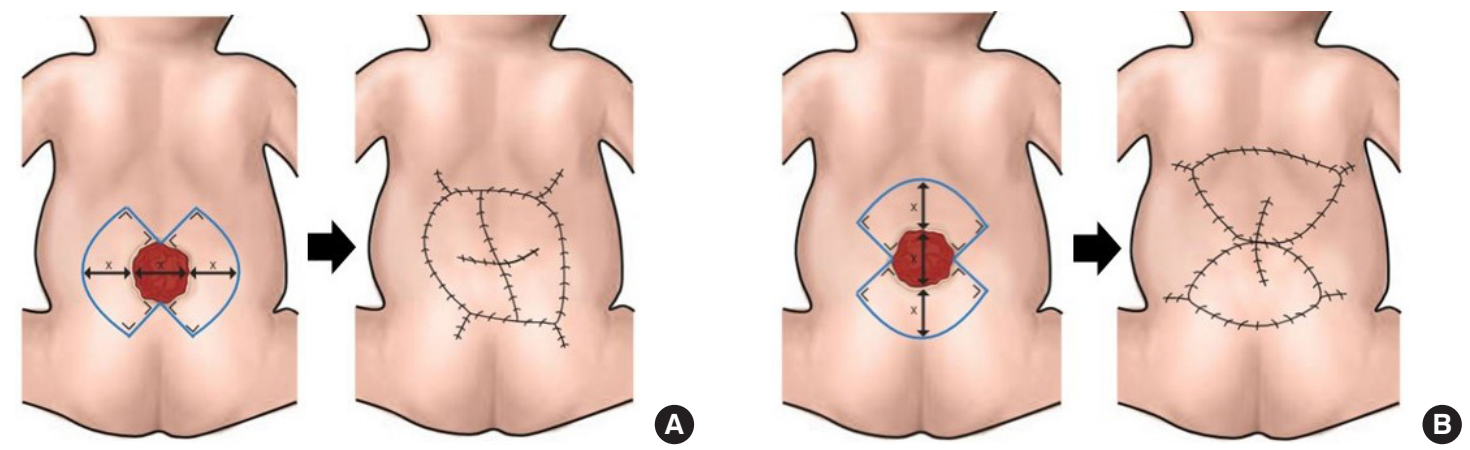

Fig. 2. The bilateral keystone flap design. Each flap width is equal to the defect width. (A) The axis of the flap can be laterolateral or (B) craniocaudal.

Table 1. Patient characteristics and surgical outcomes

\begin{tabular}{|c|c|c|c|c|c|c|c|c|c|c|c|c|}
\hline No. & $\begin{array}{l}\text { Age at } \\
\text { surgery } \\
\text { (day) }\end{array}$ & Sex & Location & $\begin{array}{l}\text { Size of } \\
\text { the defect } \\
(\mathrm{cm})\end{array}$ & $\begin{array}{l}\text { Area } \\
\left(\mathrm{cm}^{2}\right)\end{array}$ & $\begin{array}{l}\text { Defect } \\
\text { width to } \\
\text { back width } \\
\text { ratio }\end{array}$ & Type of KDPIF & $\begin{array}{l}\text { Duration } \\
\text { of surgery } \\
\text { (min) }\end{array}$ & Complications & $\begin{array}{l}\text { Length of } \\
\text { hospital } \\
\text { stay (day) }\end{array}$ & $\begin{array}{c}\text { Final } \\
\text { outcome }\end{array}$ & $\begin{array}{l}\text { Long-term } \\
\text { follow-up } \\
\text { period (mon) }\end{array}$ \\
\hline 1 & 75 & M & Lumbar & $5 \times 3$ & 11.8 & 0.45 & III, laterolateral axis & 90 & $\begin{array}{r}\text { Small wound } \\
\text { dehiscence }\end{array}$ & 11 & $\begin{array}{r}\text { Complete } \\
\text { healing }\end{array}$ & Died, age 11 \\
\hline 2 & 11 & M & Lumbosacral & $5 \times 3$ & 11.8 & 0.30 & $\| \mathrm{A}$ & 85 & $\begin{array}{r}\text { Small wound } \\
\text { dehiscence }\end{array}$ & 10 & $\begin{array}{r}\text { Complete } \\
\text { healing }\end{array}$ & 44 \\
\hline 3 & 10 & $\mathrm{~F}$ & Thoracolumbar & $6 \times 6.5$ & 30.6 & 0.71 & $\begin{array}{l}\text { Bilateral IV with } \\
\text { craniocaudal axis }\end{array}$ & 120 & $\begin{array}{r}\text { Small wound } \\
\text { dehiscence }\end{array}$ & 30 & $\begin{array}{r}\text { Complete } \\
\text { healing }\end{array}$ & Died, age 18 \\
\hline 4 & 5 & M & Thoracolumbar & $6 \times 6$ & 28.3 & 0.42 & $\begin{array}{l}\text { Bilateral IV with } \\
\text { craniocaudal axis }\end{array}$ & 120 & $\begin{array}{r}\text { Small wound } \\
\text { dehiscence }\end{array}$ & 11 & $\begin{array}{r}\text { Complete } \\
\text { healing }\end{array}$ & Lost to follow-up \\
\hline 5 & 5 & $\mathrm{~F}$ & Thoracolumbar & $4 \times 4$ & 12.6 & 0.40 & Unilateral IV & 75 & None & 10 & $\begin{array}{r}\text { Complete } \\
\text { healing }\end{array}$ & 45 \\
\hline 6 & 10 & M & Thoracolumbar & $7 \times 6$ & 33 & 0.70 & $\begin{array}{l}\text { III laterolateral axis } \\
\text { with type IV } \\
\text { (omega) on } 1 \text { side }\end{array}$ & 120 & $\begin{array}{l}\text { Small wound } \\
\text { dehiscence }\end{array}$ & 42 & $\begin{array}{r}\text { Complete } \\
\text { healing }\end{array}$ & Died, age 5 \\
\hline 7 & 113 & M & Lumbar & $7.7 \times 6$ & 36.3 & 0.50 & Unilateral IV & 105 & None & 7 & $\begin{array}{r}\text { Complete } \\
\text { healing }\end{array}$ & 24 \\
\hline 8 & 16 & M & Thoracolumbar & $7 \times 6$ & 33 & 0.70 & $\begin{array}{l}\text { Bilateral IV with } \\
\text { laterolateral axis }\end{array}$ & 120 & $\begin{array}{l}\text { Necrosis in the } \\
\text { marginal } \\
\text { suture site of } \\
\text { the flap }\end{array}$ & 70 & $\begin{array}{r}\text { Complete } \\
\text { healing }\end{array}$ & Died, age 15 \\
\hline 9 & 7 & M & Lumbosacral & $4 \times 4$ & 12.6 & 0.29 & $\| A$ & 90 & None & 20 & $\begin{array}{r}\text { Complete } \\
\text { healing }\end{array}$ & 18 \\
\hline 10 & 369 & M & Thoracolumbar & $10 \times 7$ & 55 & 0.70 & $\begin{array}{l}\text { Bilateral IV with } \\
\text { laterolateral axis }\end{array}$ & 120 & None & 10 & $\begin{array}{r}\text { Complete } \\
\text { healing }\end{array}$ & 6 \\
\hline 11 & 1 & $\mathrm{~F}$ & Lumbar & $3 \times 3$ & 7.1 & 0.44 & Unilateral IV & 60 & None & 18 & $\begin{array}{r}\text { Complete } \\
\text { healing }\end{array}$ & 10 \\
\hline 12 & 1 & $\mathrm{~F}$ & Lumbosacral & $3.5 \times 4$ & 11 & 0.45 & Unilateral IV & 60 & None & 12 & $\begin{array}{r}\text { Complete } \\
\text { healing }\end{array}$ & 2 \\
\hline 13 & 35 & M & Lumbosacral & $3.5 \times 6$ & 16 & 0.60 & Unilateral IV & 45 & None & 14 & $\begin{array}{r}\text { Complete } \\
\text { healing }\end{array}$ & 2 \\
\hline 14 & 20 & $\mathrm{~F}$ & Thoracolumbar & $4 \times 5$ & 15.7 & 0.56 & Unilateral IV & 45 & None & 9 & $\begin{array}{r}\text { Complete } \\
\text { healing }\end{array}$ & 2 \\
\hline
\end{tabular}

KDPIF, keystone-design perforator island flap; $\mathrm{M}$, male; $\mathrm{F}$, female. 

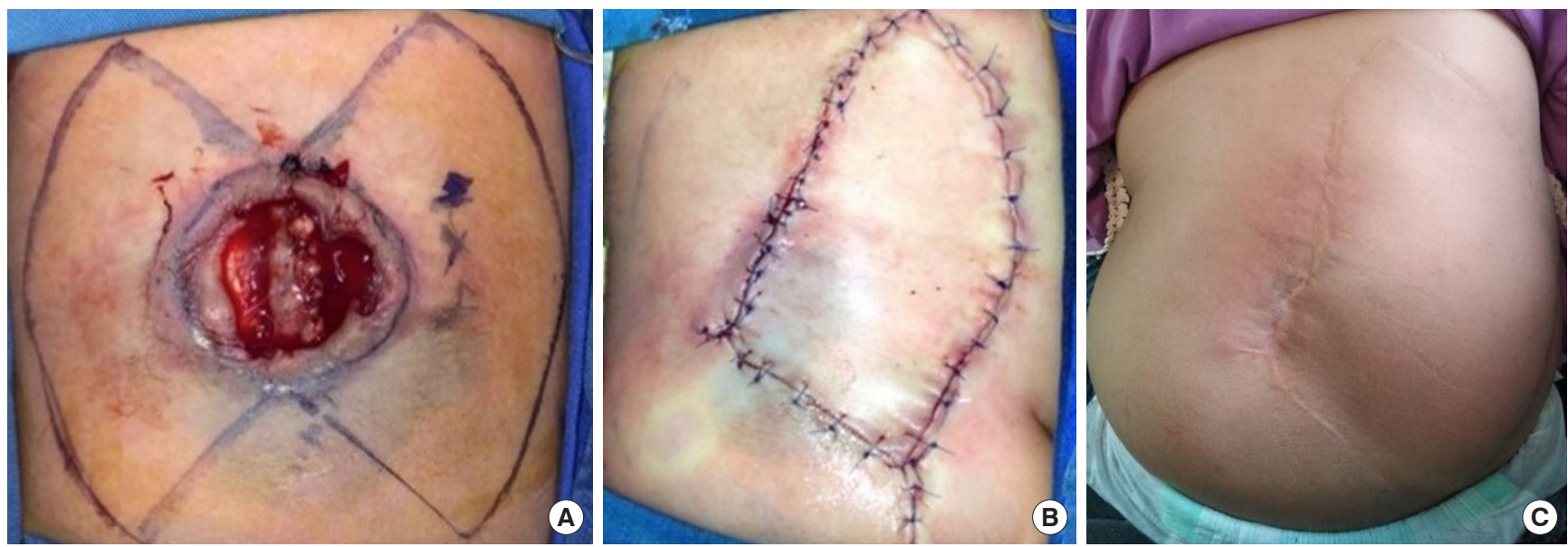

Fig. 3. A case of patient 5. Thoracolumbar meningomyelocele reconstruction with a keystone-design perforator island flap. (A) The design of the keystone flap can be made from either side or bilaterally. (B) A unilateral type IV keystone flap from the right side of the defect was used, with the final suture lines passing through the midline of vertebrae. (C) Long-term follow-up at 45 months with no complications.
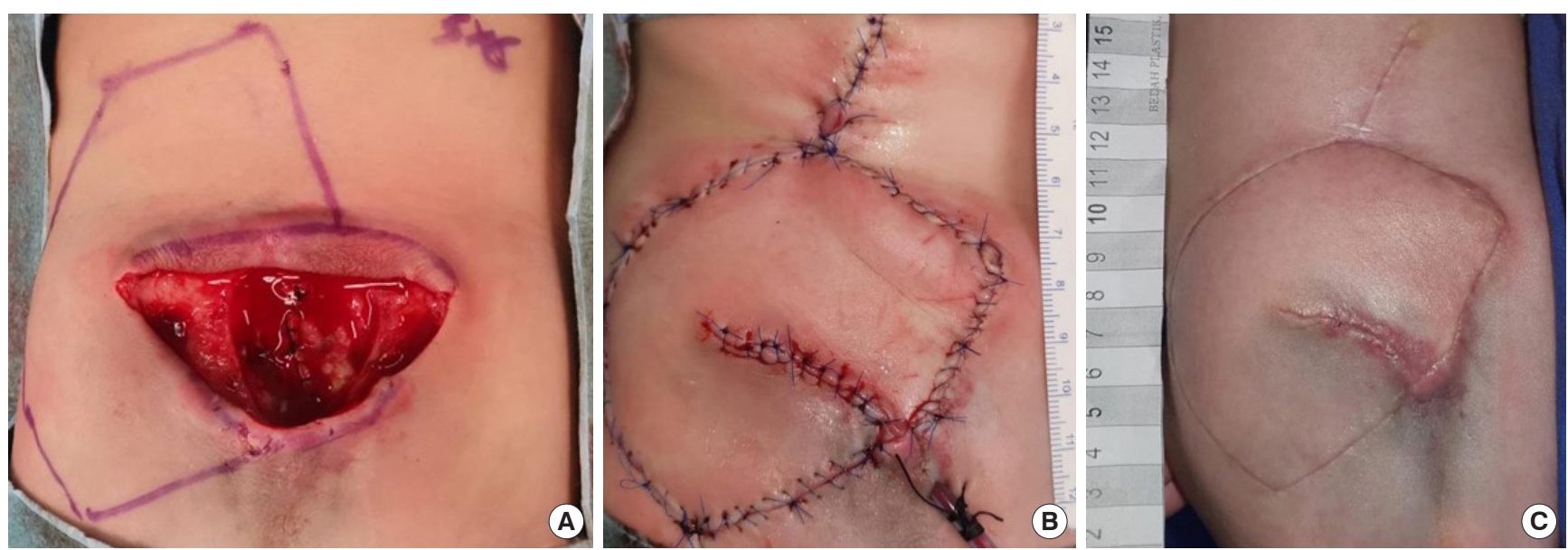

Fig. 4. A case of patient 13. A modified keystone flap design. (A) Design of a unilateral keystone flap. (B) Omega modification of a type IV keystone flap. (C) At 2 months of follow-up with no complications.

flaps were used to cover two defects. Six defects were closed with unilateral type IV keystone flaps (Figs. 3, 4) and four defects were closed with bilateral type IV flaps with a craniocaudal axis or laterolateral axis (Fig. 5). Smaller defects $\left(<15 \mathrm{~cm}^{2}\right)$ tended to be closed with type II keystone flaps and larger defects $\left(>30 \mathrm{~cm}^{2}\right)$ were more often closed with bilateral type IV keystone flaps.

There were no major postoperative complications that required immediate revision surgery (e.g., flap loss or CSF leak). Six patients suffered from minor complications. Five patients had small areas of wound dehiscence (less than $2 \mathrm{~cm}$ long), mainly in the midline region where the tension was highest. One patient had a small area of necrosis in the medial marginal suture site of the flap (Fig. 6). All cases of wound dehiscence and flap necrosis healed secondarily without compromising the neural structure underneath. Five out of six minor complica-
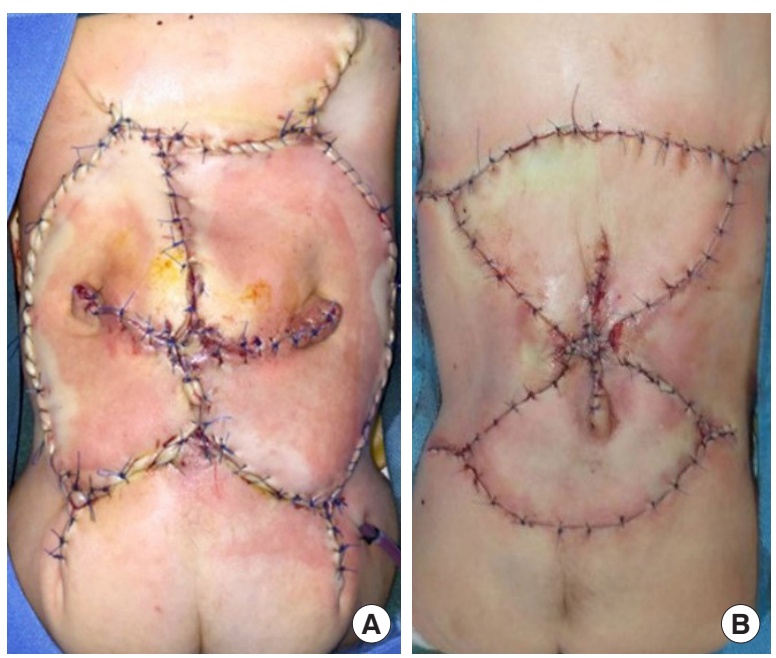

Fig. 5. Various types of keystone-design perforator island flaps. (A) Bilateral keystone flap with laterolateral axis. (B) Craniocaudal axis. 

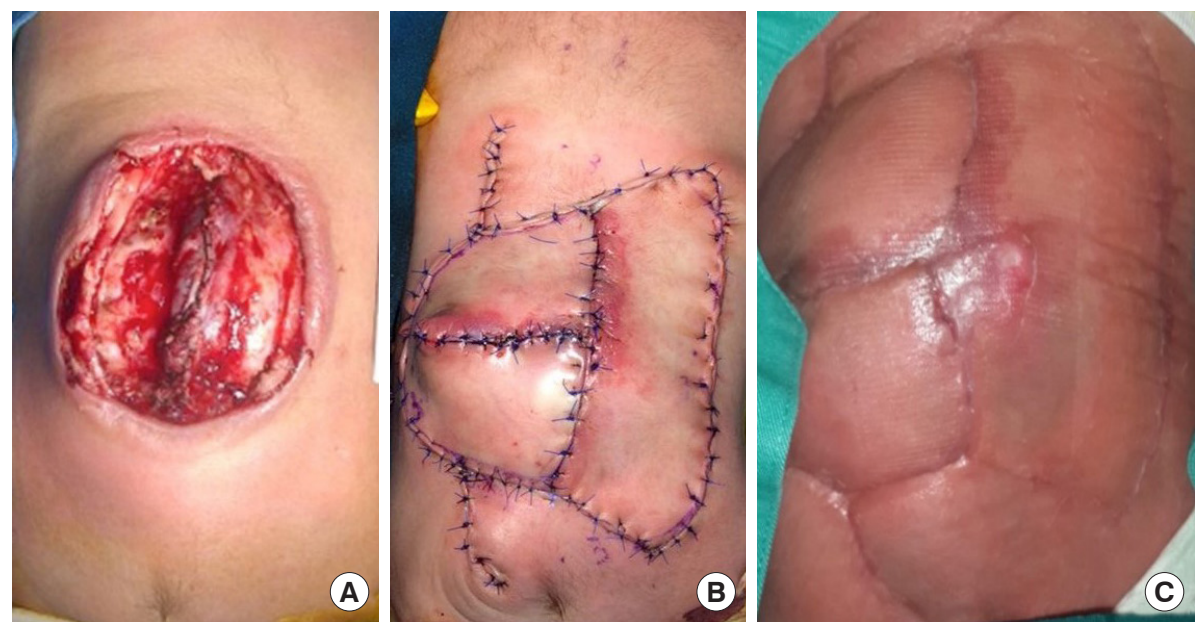

Fig. 6. A case of patient 7. (A) Large meningomyelocele defect reconstruction. (B) A type III keystone flap design was used, with omega modification on one side. (C) Wound dehiscence was noted at the marginal suture site of the flap, with eventual complete healing by secondary intention at 2 months postoperatively.

tions occurred in the cases where bilateral flaps were used. Two patients had a hospital stay of more than a month due to respiratory and cardiac problems. The longer hospital stays were not associated with the wound healing of the flap or dehiscence of the flap. At a long-term follow-up evaluation, all patients had complete wound healing, while four patients died due to associated diseases (ventriculoperitoneal shunt infection, respiratory and cardiac problems).

\section{DISCUSSION}

The aim of meningomyelocele reconstruction is to prevent ascending infection of the central nervous system and provide durable skin and soft tissue coverage of the defect with minimal morbidity [1-3]. Most meningomyelocele defects can be closed primarily. However, the repair of larger defects may be challenging due to inadequate soft tissue coverage and tension at the wound closure site [15]. Several studies have reported complications related to defect closure such as flap loss, dehiscence, CSF leaks, dural exposure, hydrocephalus, and sepsis, with rates ranging between $0 \%$ and $22.8 \%[3,6,7]$. Our study showed that six out of 14 patients showed only minor complications, such as small wound dehiscence and small areas of flap necrosis. Nevertheless, all patients showed complete wound healing without revision surgery.

There are no fixed criteria that guide surgeons regarding the technique used for defect closure. One study suggested that defects larger than $20-25 \mathrm{~cm}^{2}$ required further reconstruction by plastic surgeons [16]. Another study by Ozcelik et al. [17] stated that cases with tissue deficits more than $18 \mathrm{~cm}^{2}$ require more complex reconstruction. At our institution, the plastic surgery unit was consulted for patients with defects as small as $7.1 \mathrm{~cm}^{2}$ to larger defects $\left(55 \mathrm{~cm}^{2}\right)$ for defect reconstruction using $\mathrm{KD}$ PIFs.

The authors used KDPIFs for meningomyelocele defect closure because this one-stage procedure provided stable coverage using tissue adjacent to the defects, which gave a "like-to-like" effect and maintained sensibility with no to minimal donor morbidity. Other advantages included the short operative time and the simple technique of flap design and elevation. The decision of which type of keystone flap to use was based on intraoperative findings. This included the size of the defect, the size and quality of adjacent tissue (the infant's size), the laxity of the skin, and the presence of an associated bone deformity such as kyphosis. Smaller defects $\left(<15 \mathrm{~cm}^{2}\right)$ tended to be closed with type II keystone flaps and larger defects $\left(>30 \mathrm{~cm}^{2}\right)$ were more often closed with bilateral type IV keystone flaps. If bilateral flaps are used, the axis of the flap can be either laterolateral or craniocaudal, depending on the laxity of the skin surrounding the defects. The total flap width of bilateral flaps is larger than unilateral flaps to accommodate flap mobility reduce skin tension. However, bilateral flaps still have a weak point on the center where the marginal areas of the flap meet. This can lead to tension and wound breakdown. Because of the higher chance of developing complications at the suture site, we recommend the use of unilateral KDPIFs and their modifications.

Eight previous studies have discussed the use of KDPIFs for meningomyelocele defect closure [15,18-24]. All of those studies also demonstrated satisfactory experiences in using KDPIFs for meningomyelocele closure. The studies by Gutman et al. [15], Park et al. [19], Jamjoom et al. [20], Mrad et al. [21], and Gomez and Barrera [22] reported no complications after defect 
closure using keystone flaps in between one and five patients. Donaldson et al. [18] reported that two out of six patients had wound complications after surgery. Both Formentin et al. [23] and Hifny and Hamdan [24] reported that one patient out of seven had complications. To our knowledge, our study is the largest clinical case series of keystone flaps for meningomyelocele defect closure with 14 patients with no major complication such as CSF leaks. All previous studies mainly used type III keystone flaps. Hifny and Hamdan [24] used type II keystone flaps in two patients and Gomez and Barrera [22] used type IV keystone flaps in two patients. In our study, we presented various types of keystone flaps to close defects with different sizes, and we proposed an algorithm for the reconstruction of meningomyelocele defects using keystone flaps based on the size of the defects and the proportion of the width of the defect to the width of the patient's back (Fig. 7).

In our series, only two patients underwent surgery within the first 24 hours of life. However, three patients underwent surgery at a very late age $(75,113$, and 369 days). Delayed closure may be associated with an increased incidence of meningitis. The surgical repair of the sacs is different from early closure because they are epithelialized and may have undergone changes due to previous infections [2]. Based on our experience, tissue laxity in older children may be diminished due to the presence of scarring and fibrosis; therefore, tissue mobilization is limited compared to younger patients. For this reason, when designing the keystone flap, a wider flap or a double keystone flap may be required to close a relatively small defect. One of our patients with an age of 75 days and defect size of $11.6 \mathrm{~cm}^{2}$ underwent closure with a type III KDPIF.

Patel et al. [10] recommended placing a linear skin suture in the midline during myelomeningocele repair because patients often require additional surgery involving the posterior trunk. On the contrary, we encourage positioning the final skin suture across the midline to avoid overlapping between the skin closure line and dural closure line. We postulate that there is a higher chance of wound breakdown if sutures are placed in the midline. If the dural repair is not patent, then the CSF can leak through the skin, increasing the risk of meningitis.

In terms of operative time, our study showed comparable results to previous research on meningomyelocele defect closure. Ulusoy et al. [25] reported 10 cases of meningomyelocele defect closures using bilateral modified V-Y closures with an average operative time of 51.7 minutes. Sharma et al. [26] reported closures using direct repair, Limberg flaps, double rotation flaps, triple rotation flaps, and local transposition flaps with average operative times of $43.25,59.55,65,90$, and 57.5 minutes respectively. Among 28 patients who underwent rotation/advancement flap closures, Gursoy et al. [27] noted an average operative time of 86.25 minutes for single flaps, 115.45 minutes for double flaps, and 170.38 minutes for four-flap closures. In previous studies using keystone flap closures for meningomyelocele, Gutman et al. [15], Donaldson et al. [18], Park et al. [19], Hifny and Hamdan [24] reported average operative times of 223, 236, 225 , and 86 minutes, respectively. Our study showed an average of 89.6 minutes, with 70.6 minutes on average for unilateral key-

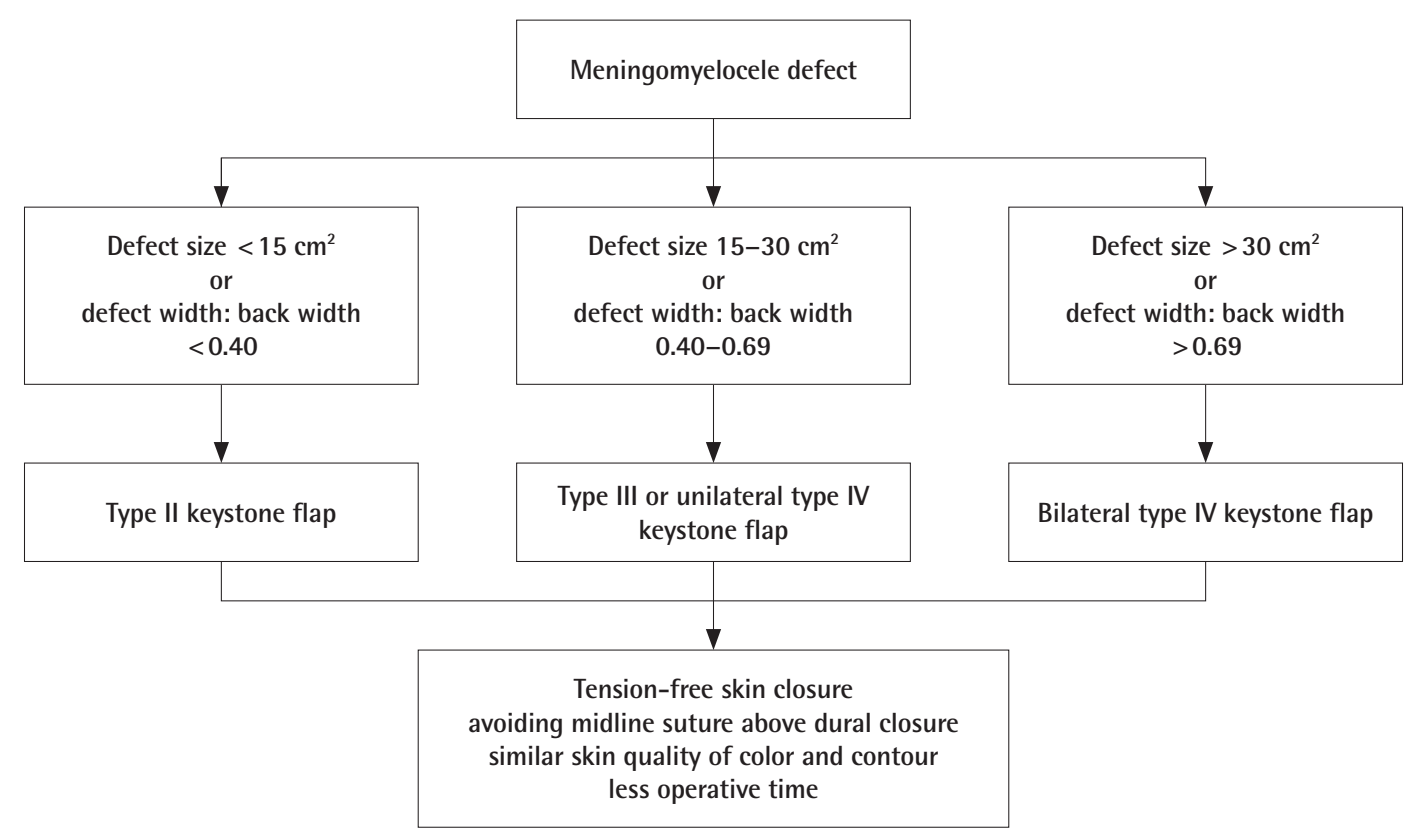

Fig. 7. Meningomyelocele defect reconstruction using keystone flaps. 
stone flaps and 115 minutes for bilateral keystone flaps.

This series demonstrated that KDPIFs were successfully implemented as locoregional fasciocutaneous flaps in the reconstruction of large meningomyelocele defects. Previous studies have described that this flap provided adequate tissue bulk, had reliable vascularization, and great versatility [16]. More complicated modalities, such as musculocutaneous flaps, may not be needed. Musculocutaneous flaps are associated with higher blood loss, longer operative time, and donor-site morbidity $[6,7]$. One study pointed out that the latissimus dorsi muscle should be preserved because it plays a vital role in supporting the body for patients with paraplegia. Furthermore, harvesting a muscle flap from the gluteal region may create a large scar that initiates future pressure wounds because many patients have neurological deficits that limit mobilization [6].

The overall outcomes of KDPIFs for meningomyelocele defect closure were satisfactory. The strengths of our study included the number of patients, the utilization of several types of keystone flap designs, the relatively long follow-up period, and the proposed algorithm of reconstruction. A major limitation of our study is the lack of a control group comparing keystone flaps with other methods or other types of flaps for meningomyelocele defect closure.

In conclusion, our study demonstrates that the KDPIF is a reliable, easy, and fast technique to cover challenging large meningomyelocele defects with a high success rate. This procedure offers several distinct advantages over other techniques in closing meningomyelocele defects: (1) any large defect at the thoracal, lumbar, and sacral region can be closed; (2) the fasciocutaneous flap provides good vascularization; (3) this flap requires no delayed procedures (i.e., it is a one-stage operation); (4) many modifications on the axis of movement of the flaps can be made; and (5) unilateral KDPIFs result in faster operative times with fewer complications.

\section{NOTES}

\section{Conflict of interest}

No potential conflict of interest relevant to this article was reported.

\section{Ethical approval}

The study was approved by the Faculty of Medicine Universitas Indonesia Ethical Committee for Medical Research (No. KET185/UN2.F1/ETIK/PPM.00.02/2020) with research protocol number 20-02-0181 and performed in accordance with the principles of the Declaration of Helsinki.

\section{Patient consent}

The patient's guardians provided written informed consent for the publication and the use of patient's images.

\section{Author contribution}

Conceptualization: NM Putri. Data curation: all authors. Formal analysis: NM Putri, N Tunjung. Methodology: all authors. Project administration: NM Putri, N Tunjung. Resources: NM Putri. Supervision: NM Putri. Validation and visualization: all authors. Writing - original draft: N Tunjung, PM Sadikin. Writing - review and editing: NM Putri, N Tunjung. Approval of final manuscript: all authors.

\section{ORCID}

Nandita Melati Putri https://orcid.org/0000-0003-0839-7877 Narottama Tunjung https://orcid.org/0000-0003-2785-405X Patricia Marcellina Sadikin

https://orcid.org/0000-0002-1381-9299

\section{REFERENCES}

1. Duffy FJ Jr, Weprin BE, Swift DM. A new approach to closure of large lumbosacral myelomeningoceles: the superior gluteal artery perforator flap. Plast Reconstr Surg 2004;114: 1864-70.

2. Watson JC, Tye G, Ward JD. Delayed repair of myelomeningoceles. World Neurosurg 2014;81:428-30.

3. Oakeshott P, Hunt GM. Long-term outcome in open spina bifida. Br J Gen Pract 2003;53:632-6.

4. Di Rocco C, Trevisi G, Massimi L. Myelomeningocele: an overview. World Neurosurg 2014;81:294-5.

5. Caldarelli M, Rocco CD. Myelomeningocele primary repair surgical technique. In: Ozek MM, Cinalli G, Maixner WJ, editors. Spina bifida: management and outcome. Milano: Springer; 2008. p. 143-55.

6. Musluman AM, Karsidag S, Sucu DO, et al. Clinical outcomes of myelomeningocele defect closure over 10 years. J Clin Neurosci 2012;19:984-90.

7. Kobraei EM, Ricci JA, Vasconez HC, et al. A comparison of techniques for myelomeningocele defect closure in the neonatal period. Childs Nerv Syst 2014;30:1535-41.

8. Cologlu H, Ozkan B, Uysal AC, et al. Bilateral propeller flap closure of large meningomyelocele defects. Ann Plast Surg 2014;73:68-73.

9. Jabaiti S, Al-Zaben KR, Saleh Q, et al. Fasciocutaneous flap reconstruction after repair of meningomyelocele: technique and outcome. Pediatr Neurosurg 2015;50:344-9.

10. Patel KB, Taghinia AH, Proctor MR, et al. Extradural myelo- 
meningocele reconstruction using local turnover fascial flaps and midline linear skin closure. J Plast Reconstr Aesthet Surg 2012;65:1569-72.

11. de Weerd L, Weum S, Sjavik K, et al. A new approach in the repair of a myelomeningocele using amnion and a sensate perforator flap. J Plast Reconstr Aesthet Surg 2013;66:8603.

12. Hallock GG. Reconstruction of posterior trunk defects. Semin Plast Surg 2011;25:78-85.

13. Behan FC. The Keystone Design Perforator Island Flap in reconstructive surgery. ANZ J Surg 2003;73:112-20.

14. Gomez OJ, Baron OI, Penarredonda ML. Keystone flap: overcoming paradigms. Plast Reconstr Surg Glob Open 2019;7:e2126.

15. Gutman MJ, Goldschlager T, Fahardieh RD, et al. Keystone design perforator island flap for closure of myelomeningocele. Childs Nerv Syst 2011;27:1459-63.

16. de Chalain TM, Cohen SR, Burstein FD, et al. Decision making in primary surgical repair of myelomeningoceles. Ann Plast Surg 1995;35:272-8.

17. Ozcelik D, Yildiz KH, Is M, et al. Soft tissue closure and plastic surgical aspects of large dorsal myelomeningocele defects (review of techniques). Neurosurg Rev 2005;28:218-25.

18. Donaldson C, Murday HK, Gutman MJ, et al. Long-term follow-up for keystone design perforator island flap for closure of myelomeningocele. Childs Nerv Syst 2018;34:733-6.

19. Park HS, Morrison E, Lo C, et al. An application of keystone perforator island flap for closure of lumbosacral myelomeningocele defects. Ann Plast Surg 2016;77:332-6.

20. Jamjoom H, Alnoman H, Almadani Y. Closure of a large thoracolumbar myelomeningocele using a modified bilateral keystone flap. Plast Reconstr Surg Glob Open 2016;4:e1114.

21. Mrad MA, Alharbi A, Mahabbat N, et al. Surgical application of the keystone island flap for closure of thoracolumbar myelomeningocele defects: a case report. Ann Med Surg (Lond) 2020;57:339-42.

22. Gomez O, Barrera C. Keystone flap: a safe coverage option in the handling of salvage for myelomeningocele. Childs Nerv Syst 2020;36:2765-74.

23. Formentin C, de Andrade EJ, Matias LG, et al. Using the keystone design perforator island flap in large myelomeningocele closure. Neurosurg Focus 2019;47:E19.

24. Hifny MA, Hamdan AR. The keystone island perforator flap in reconstruction of large myelomeningocele defects. Ann Plast Surg 2020;84:575-9.

25. Ulusoy MG, Kocer U, Sungur N, et al. Closure of meningomyelocele defects with bilateral modified V-Y advancement flaps. Ann Plast Surg 2005;54:640-4.

26. Sharma MK, Kumar N, Jha MK, et al. Experience with various reconstructive techniques for meningomyelocele defect closure in India. JPRAS Open 2019;21:75-85.

27. Gursoy K, Ustun GG, Akduman B, et al. Analysis of wound complications of patients with meningomyelocele. Turk J Plast Surg 2020;28:19-24. 